THURSDAY, JUNE 29, 1876

\section{GOVERNMENT AID TO SCIENTIFIC RESEARCH}

TE publish below a correspondence which we cannot but regard with the greatest satisfaction; Government has at last seen it to be its duty to act upon the recommendation of the Duke of Devonshire's Commission, and make a substantial contribution towards the endowment of pure scientific research. We need scarcely remind our readers that from the first we have maintained that such endowment is the duty and interest of civilised states. But indeed it is long since the British Government practically acknowledged this to be the case; the grant of 1,000 . yearly to the Royal Society for purposes of research was first made twenty-five years ago. We hope the additional 4,000l., making up 5,000l., will be put to such excellent use that Government will not only renew the grant at the end of the five years, but see the necessity of increasing it to at least the sum suggested when the $1,000 l$. was first granted. No doubt the first to bring the duty of the State in respect to science prominently before the public in this country was the late Colonel. Strange. He broached his scheme many years ago at the Norwich meeting of the British Association, and by his earnest and untiring advocacy he soon gained to his views most of the scientific men of the country, and Government became so impressed with the importance of the subject that the Science Commission was appointed in I870. The substance of the various Reports of this Commission is familiar to our readers ; the mass of evidence it has elicited has probably done more than anything else to enlighten the country and our Government as to the high importance and wide extent of scientific research. We can hardly expect Government to carry out all at once the recommendations of the Commissioners as to the extent to which unremunerative research should be assisted; but no doubt the 4,000l. which is to be annually entrusted to the administration of the Royal Society for the next five years, is the first, partly tentative step towards this. Then there were the strong words of Lord Derby, at Edirburgh, last December (see NATURE, vol, xiii. p. I4I) : "I think," he said, "that more liberal assistance in the prosecution of original scientific research is one of the recognised wants of our time." As the natural outcome of all this, and no doubt mainly as the result of the recommendations of the Science Commission, the Government has resolved to try what good results are likely to follow from a first and moderate endowment. We think we may safely prophecy that the result is likely in time to lead to the increase of the grant to at least the sum proposed to be entrusted to the Royal Society twenty-five years ago.

The difference between this new grant of 4,000l. and that of the old $1,000 \mathrm{l}$, should be noted. In the case of the latter the money had to be expended on instruments, ixc., by the recipients, whereas in the case of the new grant the endowment may be personal; the grants may be made to individuals not merely to provide themselves with apparatus, but as a means of sustenance while prosecuting

VoL, xIV.-No. $34^{8}$ scientific researches incompatible with the pursuit of an ordinary means of livelihood. And here we should remark that we never advocated in these columns the wholesale selection of untried youths for the receipt of such endowments, nor is it meant thus to allocate the grant which has been made. The selection will be made from among those who by the work which they have already done have proved themselves capable of making a profitable use of the endowment.

Another point in the conditions attending the new grant we notice with pleasure, namely, the reconstruction of the Government Grant Committee of the Royal Society, so as to include the Presidents of the principal Scotch and Irish Societies, as well as those of the chief London scientific bodies. Thus the interests of Scotland and Ireland are as well cared for in this matter as those of England.

The Royal Society has now a great responsibility resting upon it. What with the annual 4,000l. from Government, in addition to the previous $\mathrm{I}, 000 \mathrm{l}$, and the 6,000\% which Mr. Jodrell has entrusted to its administration, it will have critical and important duties to science and to the country to perform. We are sure it will take every care so to allot these funds as to prove that it has only the interests of pure science at heart, and is quite competent to carry out the intentions of Government as well as of private donors.

The following is the correspondence in relation to the grant which has passed between Government and the Royal Society :-

Letter to tha President of the Royal Society.

Science and Art Department, South Fensington, S. W., April 29, $\times 876$

SIR,-Her Majesty's Government have had under their consideration the question of giving some further aid to scientific research.

As you are aware a sum of 1,000 l. is voted annually by Parliament "to enable the Royal Society to defray the expenses of scientific investigations considered by a Committee of the Society to be worthy of such aid." This Committee, called the Government Grant Committee, consists of the President and Council of the Royal Society and twenty-one other gentlemen of scientific eminence not members of the Council ; and the Grant is expended in aiding investigators to provide themselves with apparatus and assistants, but never in personal payments to the investigators themselves.

It is proposed that this action of the State should be extended, and that further aid should be given to research by according permission to the Government Grant Committee to recommend in certain cases the payment of personal allowances to gentlemen during the time they are engaged in their investigations; that a sum of $5,000 l$., including the above-mentioned I,oool., should be taken annually; that the Royal Society should be invited to aid Her Majesty's Government with their advice and assistance in its appropriation and expenditure, and as to the sums to be granted in each case, reporting annually to the Lords of the Committee of Council on Education on the progress made and the desirability or non-desirability of renewing the grant; and that this experiment should be tried for five years.

The Administration and expenditure of the grant, and accountability for it, should we consider be vested in the Science and Art Department of the Committee of Council on Education by which the vote will be taken; and all instruments purchased for investigations should be left in its charge when no longer required. 
It would be advisable that the Presidents of the following Societies should be ex-officio members of the Government Grant Committee, viz. :-

The Royal Society of Edinburgh, Royal Irish Academy, Royal Astronomical Society, Mathematical Society, Chemical Society, Linnean Society, Zoological Society, Geological Society, Physical Society, Institution of Civil Engineers, Institute of Mechanical Engineers, General Council of Medical Education and Registration of the United Kingdom.

Royal College of Physicians, Royal College of Surgeons, and

British Association.

No definite rule can be laid down as to the amounts to be awarded in individual cases. These must depend upon various circumstances, especially on the amount of time which the investigator devotes to the inquiry.

There would be no objection to the application of some portion of this fund to the payment of such clerical assistance as may be found necessary.

I should feel obliged if you will consult the Council of the Royal Society on this scheme and inform me what is their opinion of it, and also give me the benefit of any suggestions as to modifications that may occur to them or to your.

I have the honour to remain, $\mathrm{Sir}$,

$$
\text { Your obedient servant, }
$$

(Signed) RICHMOND AND GORDON

Letter to the President of the Royal Society.

Science and Art Department, South Kensington, S.W., May 29, 1876

SIR, - In reference to our conversation on Monday last on the subject of the Duke of Richmond and Gordon's letter of April 29, I should feel obliged by your informing the Council of the Royal Society that the Lords of the Committee of Council on Education agree with you in thinking that, under the circumstances, it would perhaps be more advisable to leave the grant of $1,000 /$. exactly as at present. The conditions of the Lord President's letter would then apply only to the vote of $4,000 \mathrm{l}$. Should the Council of the Royal Society concur in this view, we will communicate with the Treasury on the subject. The recommendations of the Royal Society with respect to the appropriation of the $4,000 l$. must, no doubt, be liable to revision by the Minister responsible to Parliament for its due administration, and of this responsibility he cannot divest himself. But the power is one, we believe, for the exercise of which there is never likely to be occasion. Should it, however, happen that the Committee of Council on Education found it inadvisable to act on all of the recommendations of the Royal Society, the best course would probably be to give the Council an opportunity of revising them; so that, if thought desirable, the items of the grant, to which exception had been taken, might be allocated in some other way. If the Royal Society are still desirous that the grant should be accepted or rejected as a whole, the Lords of the Committee of Council on Education will of course undertake that this shall be done. But they believe on consideration that the Council will agree that such a course would be likely to have a mischievous effect, and entail great hardship on those recipients of grants who, from the success that had attended their investigations, might naturally have expected the continuance of their grants.

As respects the reports of progress, My Lords believe that the Council of the Royal Society will see that Parliament will naturally desire to have laid before them such a report from those capable of giving an opinion, as will enable them to judge of the nature and amount of work being done, and the desirability, or otherwise, of continuing the grants. It is not asked that the report should be in any great detail ; as a rule it would be sufficient if it were of a general character, unless some of the subjects should from their special nature seem to require more precise information. The Lords of the Committee of Council on Education are fully aware of the great difficulties which surround the question of the direct encouragement of research and of the labour and responsibility that must necessarily be entailed on those who undertake to organise the experiment in this country. They therefore are glad to find that they may reckon on the cordial co-operation of the Royal Society, to whom they naturally first appealed to aid them in this matter. I have the honour to be, Sir, Your obedient Servant,

J. D. Hooker, Esq., C.B., M.D., \&c., (Signed) SANDON

President of the Royal Society

$$
\begin{aligned}
& \text { LetTer to LORD SANDON. } \\
& \text { The Royal Society, Burlington House, } W \text {., } \\
& \text { Fune 2, } 1876
\end{aligned}
$$

My Lord,--With reference to your Lordship's letter to the President of the Royal Society dated May $29,1 \mathrm{am}$ to inform you that the President and Council of the Royal Society concur in the proposal therein contained, namely that, while the grant of $1,000 l$. should remain exactly as at present, a vote of $4,000 /$. should be taken on the conditions expressed in the Lord President's letter ; and that, in case it should happen that the Committee of Council on Education found it inadvisible to act on all the recommendations of the Royal Society, the Council of the Royal Society should have an opportunity of revising them, so that, if thought desirable, the items of the grant to which exception had been taken might be allocated in some other way.

$$
\begin{aligned}
& \text { I have the honour to be, my Lord, } \\
& \text { Your obedient Servant, } \\
& \text { (Signed) G. G. SToKEs, Secretary, R.S. }
\end{aligned}
$$

The Lord Sandon, \&c., \&c, \&c.

\section{WALLACE'S GEOGRAPHICAL DISTRIBUTION OF ANIMALS ${ }^{1}$}

The Geographical Distribution of Animals, with a Study of the Living and Exinct Faunas, as Elucidating the Past Changes of the Earth's Surface. By Alfred Russel Wallace. Two Vols. 8vo. (London: Macmillan and Co., 1876.)

\section{II.}

THE second part of his great work on Geographical 1 Distribution Mr. Wailace devotes to the discussion of fossil animals. It might seem at first sight, as our author observes, rather out of place to begin the systematic treatment of this subject with extinct animals rather than with recent ones. But those who take the trouble to read these most interesting chapters will be speedily convinced to the contrary. Imperfect as is our knowledge of the geological past, enough has been already ascertained to enable some enchanting theories to be started which account to a greater or less extent for some of the most difficult problems of the present. As regards the comparatively recent extirpation of large and important forms which has taken place in Europe, in North America, and in South America alike since Post-Pliocene times, "it is clear," our author tells

\footnotetext{
$x$ Continued from p. I68.
} 